\title{
Monitoring the safety of nilotinib in patients with chronic myeloid leukemia
}

\author{
Marija Pendovska $^{1 *}$, Zorica Naumovska ${ }^{2}$, Irina Panovska ${ }^{1}$ Marica Pavkovic ${ }^{1}$, \\ Goce Kalcev $^{3}$, Elizabeta Zisovska ${ }^{5}$, Evgenija Mihajloska ${ }^{6}$, Sanja Filkova $^{4}$, \\ Ljubica Suturkova ${ }^{2}$
}

\author{
${ }^{I}$ University Clinic for Hematology, Mother Teresa 17, 1000 Skopje, North Macedonia \\ ${ }^{2}$ Faculty of Pharmacy, Ss. Cyril and Methodius University, Mother Teresa 47, 1000 Skopje, North Macedonia \\ ${ }^{3}$ University of Cagliari, Cagliari, Italy \\ ${ }^{4}$ University Clinic for Gynecology and Obstetrics, Mother Teresa 17, 1000 Skopje, North Macedonia \\ ${ }^{5}$ Public Institution for the Needs of University Clinics, Institutes and Urgent Centre, \\ Ss. Cyril and Methodius University, Mother Teresa 17, 1000 Skopje, North Macedonia \\ ${ }^{6}$ Bayer DOO Ljubljana, Representative unit at Skopje, 1000 Skopje, North Macedonia
}

Received: November 2019; Accepted: December 2019

\begin{abstract}
The aim of the study was to evaluate the safety profile of nilotinib administered to chronic myeloid leukemia (CML) at patients. The study was conducted from March 2018 to May 2019 and it included 20 patients with CML in chronic phase. Of these 20 patients, 17 had previously been treated with imatinib and 3 with hydroxyurea. The mean duration of treatment with Nilotinib was 6.75 months. In nine patients treated with nilotinib (400 mg), $55 \%$ complained of fatigue, $33 \%$ of headache and $22.2 \%$ of pruritus. In five patients treated with Nilotinib $(600 \mathrm{mg}), 20 \%$ complained of headache, $40 \%$ of fatigue and $20 \%$ of pruritus. In addition, in six patients treated with nilotinib (800 mg), 50\% complained of headache and fatigue, $17 \%$ with pruritus and visual disorder was observed in $20 \%$ of cases. In the study, the adverse reactions were observed between the age of 20 and 40 and it was $7.1 \%$, in contrast to the group of patients between the age of 40 and 60 where the incidence of adverse reactions was $21.42 \%$. The incidence of adverse reactions in patients in the age group over 60 years it was $57.1 \%$. In terms of gender, the incidence of adverse reactions was equal to $50 \%$ for both men and women. In conclusion, this study showed that treatment with nilotinib was well tolerated, with adverse reactions of an easy degree. Future evaluation is necessary in order to understanding the adverse reaction of nilotinib in comparison with other tyrosine kinase inhibitors.
\end{abstract}

Keywords: nilotinib, pharmacovigilance, safety, chronic myeloid leukemia

\section{Introduction}

Chronic myeloid leukemia (CML) is cancer of bone marrow and white blood cells. The main feature of this leukemia is increased and unregulated growth of myeloid cells in the bone marrow and the accumulation of these cells in the blood. Abnormal cells observed in CML are: myeloid, erythroid, monocytic, megakaryocytic, Blymphoid, and occasionally T-lymphoid lineage (Faderl et al., 1999). The three stages in the development of CML are the blast phase, the phase of acceleration and the chronic phase. Most patients are randomly diagnosed as a result of an elevated white blood cell level during the chronic asymptomatic period. The most common findings found in patients with CML include weight loss, fatigue,

\footnotetext{
*marija.hemato@gmail.com
} 
abdominal fullness, bleeding, purpura, splenomegaly, leucocytosis, thrombocytosis, and anemia (Faderl et al., 1999). Recommendations for the management of CML have been elaborated by an international team of experts (Baccarani et al., 2006). Understanding the role of various agents and clinical hues between them in the treatment of CML is crucial to optimizing the clinical outcome of the patient. The era of introducing tyrosine kinase inhibitors (TKIs) in the treatment of CML completely changed the image and course of this life-threatening malignancy. Nilotinib belongs to the second generation of TKIs that has an extremely important role in the treatment of CML. It is one of the three drugs categorized in this category together with dasatinib and bosutinib (Etienne et al., 2010).). Nilotinib can also be used after unsuccessful treatment with two different TKIs, and it becomes a thirdgeneration drug by indication (Giles et al., 2007). We must agree that nilotinib has a leading role in the current management of CML, and has established its efficacy as a drug in the first and second line. The adverse reactions of this drug are common in clinical practice. Side effects of the higher level of the nilotinib that can endanger people's lives are often in relation to vital organs. The aim of this study was to elaborate and present the most common adverse reactions effects of nilotinib and to evaluate the safety profile of nilotinib administered to CML patients at the University Clinic for Hematology in Skopje, North Macedonia. It is important to note whether they are mild or life-threatening disorders. Adverse effects of imatinib and hydroxyurea as therapeutic options for CML are also conducted in this study. Monitoring the safety of nilotinib is of great importance to patients as well as clinicians.

\section{Materials and methods}

The study was conducted at the Clinic for Hematology in Skopje in the period from March 2018 to May 2019. The study included 20 patients from the whole state with CML in chronic phase. The average age of patients treated with nilotinib was 54.7 years. Furthermore, $15 \%$ of this group smokes cigarettes, and $10 \%$ use alcohol occasionally. In our study, these 20 patients who are now on treatment with nilotinib, previously, 17 patients of them were on therapy with imatinib and 3 patients with hydroxyurea. The study considers the side effects of the treatment with all three drugs, with particular emphasis on the occurrence of the side effects with the treatment by nilotinib. The method of collecting data from the patients consisted of an analysis of medical records, with special attention being paid to the history of the disease of each patient individually, as well as in-depth interviews and retrospective data collection. Adverse effects events associated with the nilotinib treatment alone, as well as with previous imatinib and hydroxyurea treatment options were all recorded and analyzed.
All patients with adverse events that occurred when the treatment was initiated were reported. In the case of discontinued treatment, they withdrew.

\section{Results and Discussion}

From 135 patients with CML, previously treated with imatinib and hydroxyurea, 20 patients were treated with nilotinib. At the same 20 patients, adverse reactions were observed while they were on the first line and then on the second line of treatment. Imatinib was approved for the treatment of bcr-abl positive patients with CML in 2002. It is currently considered as an initial treatment in patients in a chronic phase. In those 15 patients with CML who had previously been treated with imatinib $(400 \mathrm{mg}$ ), $73.3 \%$ of these patients experienced periorbital edema and $66.6 \%$ had muscular cramps. Apart from these, other adverse reactions such as legs pain $(80 \%)$, erythema of the skin $(20 \%)$ and disorder of hematological results $(13.3 \%)$ has been reported. Meanwhile, in the other two patients who were on treatment with imatinib $(800 \mathrm{mg})$, in $50 \%$ there was an occurrence of pruritus, leg pain, periorbital edema, erythema of the skin, and disorder of hematological response for each adverse reaction individual (Fig. 1).

In the three patients who had previously been treated with hydroxyurea, $66.6 \%$ reported pruritis and also $66.6 \%$ disorders of hematological results. $33.3 \%$ of them had leg pain, muscle pain and diarrhea for each adverse reaction individual (Fig. 2).

These 20 patients listed above were redirected to nilotinib therapy. The mean duration of treatment with nilotinib in these 20 patients was 6.75 months. As for the frequency of adverse reactions, we have received the following results: from nine patients treated with nilotinib (400 mg) of 20, $55 \%$ complained of fatigue, $33 \%$ of headache and $22.2 \%$ of pruritus. In $44 \%$, hyperlipidemia was registered and in $11.1 \%$ a disorder of the hematological response. Furthermore, five patients treated with nilotinib (600 mg), 20\% complained of headache, $40 \%$ of fatigue and $20 \%$ of pruritus. In $44 \%$, hyperlipidemia was registered, in $40 \%$ a disorder of the hematological response and in $20 \%$ an allergic reaction was registered and due to those allergic reactions, the drug was discontinued. For curiosity, when using the dose of $400 \mathrm{mg}$ of this medication, the hearing disorder was observed in $20 \%$ of patients. In addition, in the 6 patients treated with nilotinib $(800 \mathrm{mg}), 50 \%$ complained of headache and fatigue and $17 \%$ of the pruritus. In $44 \%$ hyperlipidemia was registered, in $33 \%$ a disorder of hematological response and $67 \%$ an allergic reaction where the drug also was discontinued. Interesting, when using the dose of this medication $(800 \mathrm{mg}$ ), the visual disorder was observed in $20 \%$ (Fig. 3). 


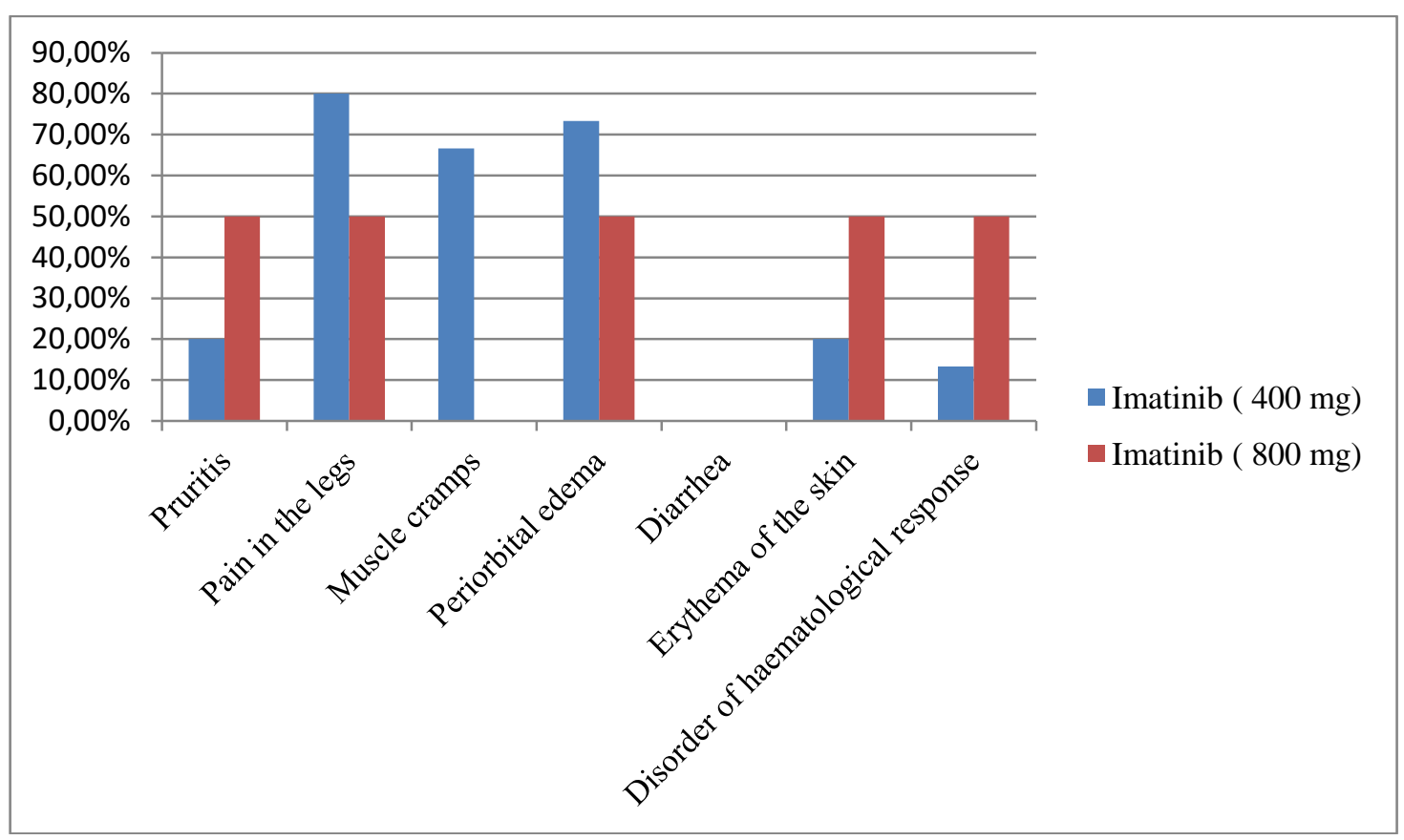

Fig. 1. Distribution of most frequent adverse reactions in patients treated with imatinib in correlation with administered dose.

On the other hand, in the 20 patients treated with nilotinib, adverse reactions were observed at almost all ages. At the patients under 20 years of age, no adverse reactions were observed. The appearance of adverse reactions between the age of 20 and 40 was $7.1 \%$, in contrast to the group of patients between the age of 40 and 60 where the incidence of adverse reactions was $21.42 \%$. The incidence of adverse reactions in patients treated with nilotinib is highest in the age group over 60 years. It was
$57.1 \%$. In terms of gender, the incidence of adverse reactions was equal to $50 \%$ for both men and women. Regarding the daily dose of nilotinib, adverse reactions were observed at $50 \%$ when using the daily dose of 800 $\mathrm{mg}, 42.8 \%$ with a daily dose of $400 \mathrm{mg}$ and $7.1 \%$ with a daily dose of $600 \mathrm{mg}$. Comorbidities have been reported in $28.57 \%$ of patients with adverse events. The most common comorbidities were from the neurological, cardiac and endocrine origin.

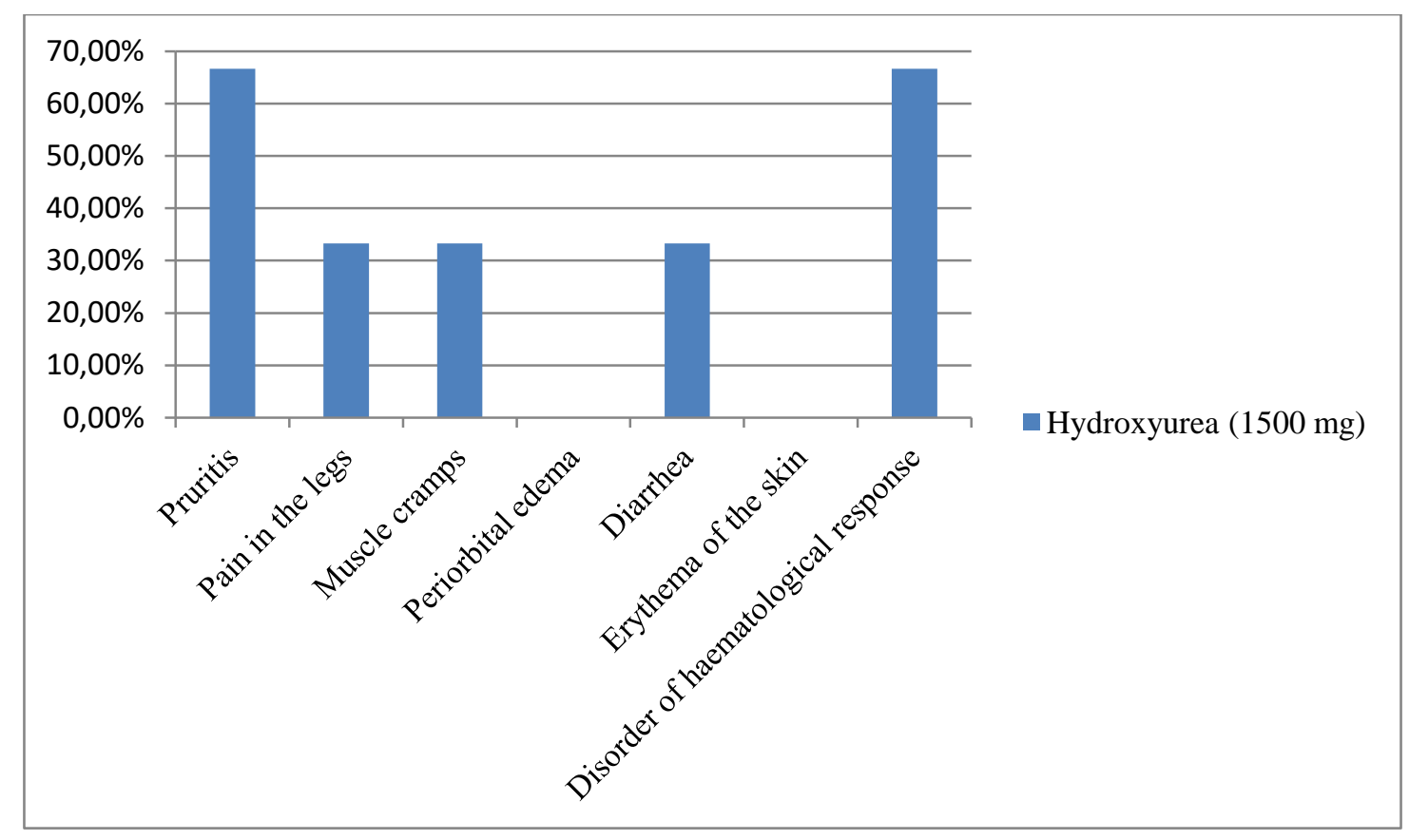

Fig. 2. Distribution of most frequent adverse reactions in patients treated with hydroxyurea.

Макед. фарм. билт., 65 (2) 67 - 72 (2019) 


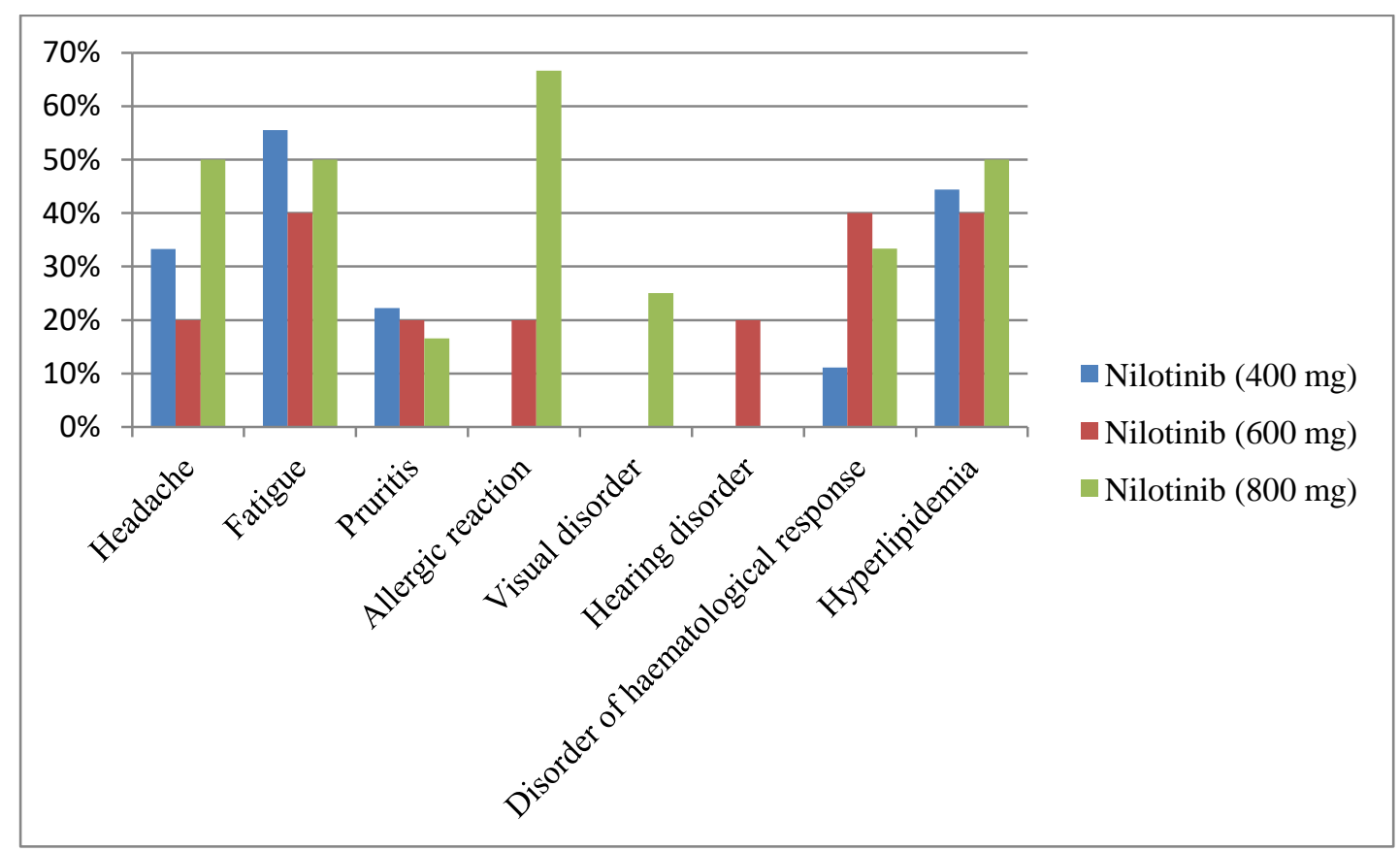

Fig. 3. Distribution of most frequent adverse reactions in patients treated with nilotinib and its adverse reactions in correlation with administered dose.

According to the WHO protocols, adverse reactions to the drug (ADR) have the following definition: "Any response to a drug that is harmful and unintentional, and which occurs at doses commonly used in humans for diagnosis, prophylaxis or therapy of the disease and for modifications of the physiological function". Negative reactions to drugs occur almost every day in any health institution. These can negatively affect the quality of life of the patient. It is a significant factor for morbidity and mortality (Gupta et al., 2011). Negative reactions can cause patients to lose their confidence, giving birth to negative emotions to the health profession and health institution. They can reach for self-treatment, which can result in negative reactions at a higher level (Schatz et al., 2015). Within this, pharmacovigilance (PV) is defined as a sum of activities related to detection, evaluation, understanding and preventing adverse reactions or any other another drug problem. WHO has set up its own International drug monitoring program in response to the thalidomide disaster discovered in 1961. The goal of PV is to improve patient care and patient safety when using drugs. It also includes public support and creation of health programs by providing reliable, balanced information on effective risk-benefit assessment profile of drugs (Spina et al., 2016).

CML is neoplasia of hematopoietic stem cell cells. The incidence of occurrence is 2 per 100000 per year. The peak age is from 50 to 55 years old (Baccarani et al., 2006). Philadelphia chromosome, a translocation product of chromosomes 9 and 22, is pathognomic for CML (Baccarani et al., 2009). Fusion protein acts as an active kinase. Kinase inhibitors such as imatinib block the activity of bcr-abl (Hochhaus et al., 2008). CML is one of the rare malignant diseases caused by one oncogene (bcrabl). This is the reason for the excellent efficacy of molecular therapy with CML (O'Brien et al., 2003).

In general, imatinib is a very well tolerated drug. Serious adverse reactions mainly affect hemopoiesis and are partly caused by its effect against leukemia. A rare but potentially dangerous adverse reactions is congestive heart failure that is observed in $0.2 \%$ to $0.6 \%$ of cases on a worldwide level (Coutre et al., 2008). At the heart of our research was the pharmacovigilance of the drug nilotinib. It included activities related to the detection, assessment, understanding, and prevention of adverse effects of this drug. In 2007, nilotinib was approved for the treatment of bcr-abl positive patients with CML. Nilotinib is administered orally twice a day. The bioavailability of nilotinib is affected by food intake. Nilotinib inhibits BCR-ABL, PDGFR, and c-Kit kinases; it is a built-in base of competitive inhibition of binding sites of BCR-ABL adenosine triphosphate (ATP). Nilotinib can prevent tyrosine phosphorylation of intracellular proteins that help signal transduction. This, in turn, prevents cell proliferation and induces apoptosis of $\mathrm{Ph}+$ cells. Nilotinib is unique in that its power is increased by factor 30 through imatinib due to its increased selectivity of $\mathrm{ABL}$ kinase and increased affinity for binding sites. Drugs that increase gastric $\mathrm{pH}$ may reduce the bioavailability of nilotinib. Because of this, the coadministration is not recommended (Carmen et al., 2008). For comparison, during a randomized study involving 717 patients in patients with newly diagnosed CML in the chronic phase of treatment with nilotinib, the lest common adverse reactions are: hematological toxicity in the form of myelosuppression, thrombocytopenia, neutropenia, 
anemia, pleural and pericardial effusion with fluid maintenance, congestive heart failure, gastrointestinal bleeding and brain hemorrhage. The most commonly reported adverse reactions reported in this study are metabolic disorders (decreased appetite), headache, nausea, constipation, vomiting, abdominal pain, pain in the upper abdomen. Other commonly reported adverse reactions include rash, pruritus, myalgia, erythema, arthralgia and fatigue. Reporting of adverse reactions after approval of the drug is very important. It allows health professionals to monitor the balance between benefit and the risk of the drug (Etienne et al., 2010).

The frequency of each adverse reaction in the study population should be correlated with the published data! Any specificity in the study population should be emphasized and eventual reason(s) for the specificity.

\section{Conclusion}

In summary, this study shows that treatment with nilotnib was well tolerated, with adverse reactions of an easy degree. None of the patients treated with nilotinib showed any life-threatening conditions such as pleural and pericardial effusion with fluid maintenance; congestive heart failure; gastrointestinal bleeding and hemorrhagic brain. In fact, nilotinib plays a very important role in the current management of CML. Proper evaluation of the side effects resulting from its use will open doctors' doors for better understanding of the site of nilotinib in comparison with other tyrosine kinase inhibitors in the treatment of CML. Clinical considerations of the toxicity of nilotinib and its interactions, models of resistance to drugs are of great importance to patients and their well-being. On the other hand, this approach will enable the optimization of therapy and adjustment of therapy for each patient individually.

\section{References}

Baccarani, M., Saglio, G., Goldman, J., Hochhaus, A., Simonsson, B., Appelbaum, F., Apperley, J., Cervantes, F., Cortes, J., Deininger, M., Gratwohl, A., Guilhot, F., Horowitz, M., Hughes, T., Kantarjian, H., Larson, R., Niederwieser, D., Silver, R., Hehlmann, R., European LeukemiaNet, 2006. Evolving concepts in the management of chronic myeloid leukemia: Recommendations from an expert panel on behalf of the European LeukemiaNet. Blood 108(6), 1809-1820. Available at: https://doi.org/10.1182/blood-2006-02-005686.

Baccarani, M., Cortes, J., Pane, F., Niederwieser, D., Saglio, G., Apperley, J., Cervantes, F., Deininger, M., Gratwohl, A., Guilhot, F., Hochhaus, A., Horowitz, M., Hughes, T., Kantarjian, H., Larson, R., Radich, J., Simonsson, B., Silver, R.T., Goldman, J., Hehlmann, R., European LeukemiaNet, 2009. Chronic myeloid leukemia: an update of concepts and management recommendations of European LeukemiaNet. J. Clin. Oncol. 27(35), 6041-6051.
Available at: https://doi.org/10.1200/JCO.2009.25.0779.

Carmen, F., Hagop, K., Jorge, C., Elias, J., 2008. Development and targeted use of nilotinib in chronic myeloid leukemia. Drug Des. Devel. Ther. 2, 233-243. Available at: https://doi.org/10.2147/dddt.s3181.

Coutre, P., Ottmann, O.G., Giles, F., Kim, D-W., Cortes, J., Gattermann, N., Apperley, J.F., Larson, R.A., Abruzzese, E., O'Brien, S.G., Kuliczkowski, K., Hochhaus, A., Mahon, H-F., Saglio, G., Gobbi, M., Kwong, Y.L., Baccarani, M., Hughes, T., Martinelli, G., Radich, J.P., Zheng, M., Shou, Y., Kantarjian. H., 2008. Nilotinib (formerly AMN107), a highly selective BCR-ABL tyrosine kinase inhibitor is active in patients with imatinib-resistant or intolerant accelerated phase chronicmyelogenous leukemia. Blood 111(4): 1834-1839. Available at: https://doi.org/10.1182/blood-2007-03-080689.

Etienne, G., Milpied, B., Réa, D., Rigal-Huguet, F., Tulliez, M., Nicolini, F.E., French Intergroup of CML (Fi-LMC group), 2010. Guidelines for the management of nilotinib (Tasigna)-induced side effects in chronic myelogenous leukemia: recommendations of French Intergroup of CML (Fi-LMC group). Bull. Cancer 97(8), 997-1009. Available at: https://doi.org/10.1684/bdc.2010.1136.

Faderl, S., Talpaz, M., Estrov, Z., O'brien, S., Kurzrock, R., Kantarjian, H.M., 1999. The biology of chronic myeloid leukemia. N. Engl. J. Med. 341, 164-172. Available at: https://doi.org/

Francis, J.G., Coutre, P., Bhalla, K.N., Ossenkoppele, G., Alimena, G., Haque, A., Gallagher, N., Kantarjian, H.M., 2007. Nilotinib therapy after dasatinib failure in patients with imatinib-resistant or -intolerant chronic myeloid leukemia $(\mathrm{CML})$ in chronic phase $(\mathrm{CP})$, accelerated phase (AP) or blast crisis (BC). Blood 110(11), 1029.

Gupta, K.B., Kumar, V., Vishvkarma, S., Shandily, R., 2011. Isoniazid-induced alopecia.

Lung India 28, 60-61. Available at: https://doi.org/10.4103/0970-2113.76304.

Hochhaus, A., Druker, B., Sawyers, C., Guilhot, F., Schiffer, C.A., Cortes, J., Niederwieser, D.W., Gambacorti-Passerini, C., Stone, R.M., Goldman, J., Fischer, T., O'Brien, S.G., Reiffers, J.J., Mone, M., Krahnke, T., Talpaz, M., Kantarjian, H.M., 2008. Favorable long-term follow-up results over 6 years for response, survival, and safety with imatinib mesylate therapy in chronic-phase chronic myeloid leukemia after failure of interferon-alpha treatment. Blood 111(3), 1039-1043. Available at: https://doi.org/10.1182/blood-2007-07-103523.

O'Brien, S.G., Guilhot, F., Larson, R.A., Gathmann, I., Baccarani, M., Cervantes, F., Cornelissen, J.J., Fischer, T., Hochhaus, A., Hughes, T., Lechner, K., Nielsen, J.L., Rousselot, P., Reiffers, J., Saglio, G., Shepherd, J., Simonsson, B., Gratwohl, A., Goldman, J.M., Kantarjian, H., Taylor, K., Verhoef, G., Bolton, A.E., Capdeville, R., Druker, B.J., IRIS Investigators, 2003. Imatinib compared with interferon and low- dose cytarabine for newly diagnosed chronic-phase chronic myeloid leukemia. N. Engl. J. Med. 348 (11), 994-1004. Available at: https://doi.org/10.1056/NEJMoa022457.

Spina, E., Trifir, Ã.G., Caputi, P.A., 2016. Pharmacovigilance in Psychiatry: An Introduction. Available at: https://doi.org/10.1007/978-3-319-24741-0_1.

Stephanie, N., Schatz, D., Weber, R.J., 2015. Adverse drug reactions. CNS/Pharmacy Practice-PSAP, 21-25.

Макед. фарм. билт., 65 (2) 67 - 72 (2019) 


\title{
Резиме
}

\section{Мониторирање на безбедносниот профил на нилотиниб кај пациенти со хронична миелоидна леукемија}

\author{
Марија Пендовска ${ }^{1 *}$, Зорица Наумовска ${ }^{2}$, Ирина Паноска ${ }^{1}$, Марица Павковиќ ${ }^{1}$, \\ Гоце Калцев ${ }^{3}$, Елизабета Зисовска ${ }^{5}$, Евгенија Михајлоска ${ }^{6}$, Сања Филкова $^{4}$, \\ Љубица Шутуркова ${ }^{2}$
}

\author{
${ }^{1}$ Универзитетска клиника за хематологија, Мајка Тереза 17, 1000 Скопје, \\ Северна Македонија \\ ${ }^{2}$ Фармацевтски факултет, Универзитет „,Св. Кирил и Методиј”, \\ Мајка Тереза 47, 1000 Скопје, Северна Македонија \\ ${ }^{3}$ Универзитет во Каљари, Каљари, Италија \\ ${ }^{4}$ Универзитетска клиника за гинекологија и акушерство, \\ Мајка Тереза 17, 1000 Скопје, Северна Македонија \\ ${ }^{5}$ Јавна институција за потребите на универзитетските клиники, институти и \\ ургентен центар, Универзитет „Св. Кирил и Методиј”, \\ Мајка Тереза 17, 1000 Скопје, Северна Македонија \\ ${ }^{6}$ Баер ДОО Љубљана, Претставништво во Скопје, 1000 Скопје, Северна Македонија
}

Клучни зборови: нилотиниб, фармаковигиланца, безбедност, хронична миелоидна леукемија

Целта на оваа студија беше да се процени безбедносниот профил на нилотинибот кој беше администриран кај пациенти со хронична миелоидна леукемија (ХМЛ). Оваа студија беше спроведена во период од март 2018 до мај 2019 година и во неа беа опфатени 20 пациенти со ХМЛ во хронична фаза. Од овие 20 пациенти, 17 претходно беа третирани со имитаниб и 3 со хидроксиуреа. Просечното времетраење на третманот со Нилотниб беше 6,75 месеци. Од девет пациенти кои беа третирани со нилотниб (400 мг), 55\% се жалеа на замор, 33\% на главоболка и $22,2 \%$ на пруритус. Од вкупно пет пациенти третирани со нилотиниб (600 мг), 20\% се пожалиле на главоболка, $40 \%$ на замор и $20 \%$ на пруритус. Покрај тоа, од вкупно шест пациенти третирани со нилотиниб (800 мг), $50 \%$ се пожалиле на главоболка и замор, $17 \%$ на пруритус, додека пак нарушување на видот е забележано во $20 \%$ од случаите. Во оваа студија, несаканите реакции беа забележани на возраст меѓу 20 и 40 години, застапени со инциденца од 7,1\%, наспроти групата на пациенти на возраст меѓу 40 и 60 години, каде што инциденцата на несакани реакции беше $21,42 \%$. Инциденцата на несакани реакции кај пациенти од возрасна група над 60 години изнесуваше $57,1 \%$. Во однос на полот, инциденцата на несакани реакции изнесуваше $50 \%$ и кај двата пола. Доаѓaме до заклучок дека оваа студија покажа дека третманот со нилотниб добро се толерира од страна на пациентите со појава на несакани реакции од лесен степен. Неопходни се истражувања и проценки во иднина со цел да се разбереат несаканите реакциии на нилотинибот во однос на останатите инхибитори на тирозин киназата. 